Nataliia Geseleva, Ph.D., Associate Professor of the Department of Digital Economics and System Analysis, Kyiv National University of Trade and Economics (Kyiv, Ukraine)

Ganna Proniuk, Ph.D., Associate Professor of the Department of Occupational Safety, Kharkiv National University of Radio Electronics (Kharkiv, Ukraine)

\title{
SYSTEM APPROACH TO LABOR PRODUCTIVITY MANAGEMENT IN MODERN CRISIS CONDITIONS
}

\begin{abstract}
The article is devoted to the development of a system approach for managing labor productivity in a company especially in crisis conditions. A company is considered as a complicated system with a certain external environment, patterns of development and internal structure. The main component of the internal structure is the personnel of the company, which the authors regard as a dissipative system, and each employee as an open system that exchanges energy and entropy with the environment. The article suggests the entropy factors of labor productivity. Based on the equilibrium state of an employee as a system, it has been shown that labor productivity can be enhanced by the motivational factor of self-improvement for each member of the work community.
\end{abstract}

Keywords: labor productivity, complex system, open system, synergy, dissipative system, entropy, attractor, bifurcation points, fluctuations, equilibrium state

Introduction. In a market economy, the enterprise is the main link with the national economy. The level of development of the whole state and the satisfaction of social needs for products and services depend on the performance of production enterprises. The condition for the development of production is the growth of labor productivity. This is an indicator of the productive activity of stuff, measured by the number of products produced per unit of working time. A high level of labor productivity is a criterion for the progressiveness of organizational form of company and management decisions.

One of the main tasks of the organization is to provide certain conditions that make it possible to perform working process in a safe and comfortable environment. The employee's emotional well-being is an important component of their overall health and depends on many factors. Especially now, when the whole world is entering a new crisis state with unpredictable social consequences due to losses associated with countermeasures against the spread of COVID-19. This is the first time that the global crisis will not be caused by 
financial factors, but will be industrial and concerning service. Obviously, states consciously sacrifice economic growth for the sake of saving lives and the economic shock of hard quarantine is inevitable. According to experts, in 2020 at the global level the economic situation will be close to a recession. This means that many economies will face a decline in exports, imports, and GDP. Regardless of whether economies can avoid a recession, the scenario for a return to growth under Covid-19 will depend on a number of factors. In particular, the extent to which demand will be delayed or lost, whether the shock will be short-term or last, and whether the structure of the economy will be damaged. The entire structure of trade and production and the global supply chain that has developed over decades of globalization are at stake. The destructive side of the crisis will be manifested in a decrease in exchange rates, a high probability of acceleration of inflation, a decline in the fundamental sectors of the economy - mining and manufacturing, tourism.

All this will inevitably affect the mental state of people. Special events associated with increasing the emotional state of an employee are commonly called job motivation. Job motivation is the process of stimulating an individual executor or group of people to work towards the goals of the organization, to the productive implementation of decisions or intended work. An ineffective motivation system can cause workers dissatisfaction, which always leads to a decrease in labor productivity. On the other hand, an effective system stimulates staff productivity and increases the efficiency of human resources.

The growth of the efficiency of social production goes through the continuous improvement of working conditions, increasing safety, reducing occupational injuries and diseases. Therefore, important in ensuring effective and productive work are: manager's knowledge of the personality of each employee, their psyche and character, attitude to work, discipline, job satisfaction and the attitude to other members of the team. Thus, each company has a social system "employee-enterprise", united by a common goal: to increase work efficiency while maintaining safety. The labor market is very sensitive to external changes. It is not surprising that it is in this sphere that the onset of the crisis is felt most quickly and, as a result, the fastest recovery occurs.

In modern production with its rather high level of technologies the decision concerning problems of increase of labor productivity without the account of psychophysiological factors is impossible. Now the priority in the way out of the crisis in the economy will be to ensure the support and balance of the national producer. One of the most important factors will be an increase in labor productivity. Labor productivity is like the 
patient's temperature: it is an indicator of the general state of health and efficiency of the enterprise, industry or country.

Thus, the application of a synergistic approach to labor management in the enterprise will determine the conditions of organization and self-organization of employee behavior (increased motivation to work) depending on the weak or strong characteristics of management parameters.

Purpose of Article. The article is devoted to the development of a system approach to managing the productivity of the company through the representation of the staff as a dissipative system, and each employee - as an open system that exchanges energy with the external environment.

Any company can be considered as a complicated open system with a certain external environment, the laws of operation and development and the internal structure, which consists of technology, management structure and work community [Єфімова 2007, с.67-72].

Enterprise staff can be considered as an open system that is self-evolving and which is united by the common purpose [Холод 2010, с. 48-51]. The system moves from internal impulses through association with other individuals, their respective layers to the outer layers of another system - the collective system. In this regard, the mathematical apparatus of synergetics (Greek Synergetikos - a joint, acting in concert) should be effective in studying the management problems of such systems. According to him, the set of interacting particles acquires the ability to self-organization if this set forms an open system capable of exchanging energy, mass and information with the environment. If this system is capable of evolving, it is called a dissipative system.

Synergistic approach in the investigation of collective systems. In the synergistic approach in the investigation of any collective system, it is possible to analyze the situations associated with the management of anthropogenic factor, taking into account the relationship between the layers formed by the movement of the system towards the goal. Synergetics suggests that any complexly organized system has many own ways of development that are in line with its nature. The vector of system development will be directed towards the most attractive points of development, to which the trajectory of the system directs (Fig. 1). It should also be taken into account that any system in a state between two attractors will be unstable and will require additional external influences (i.e. external energy). 


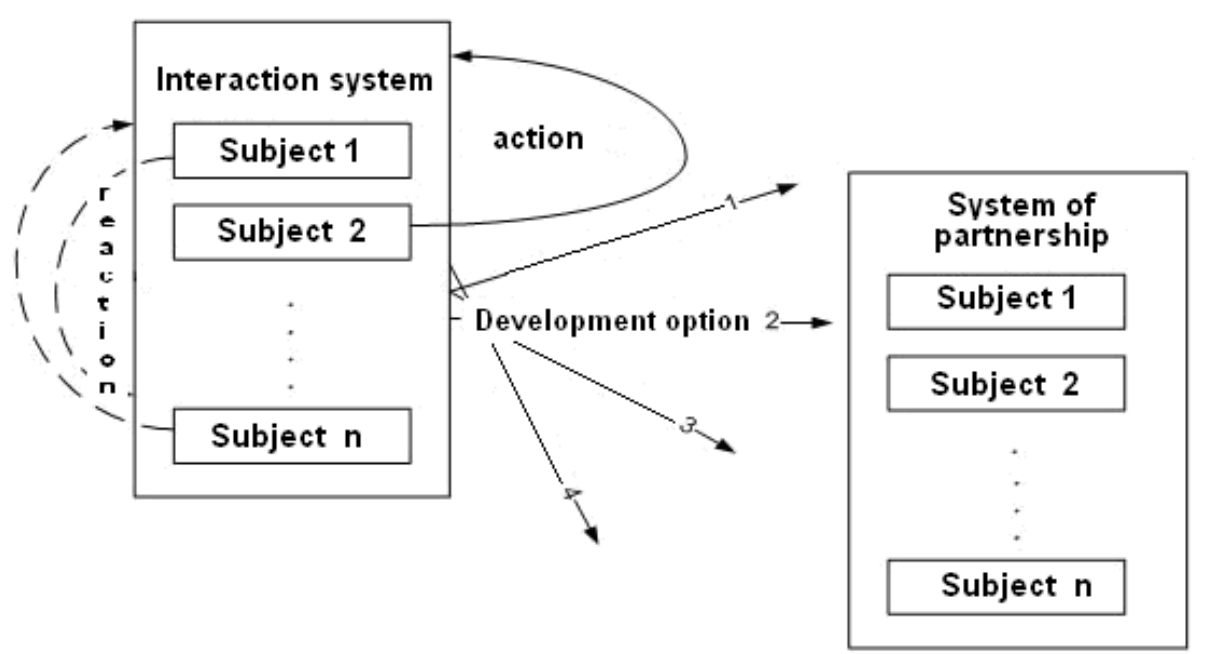

Figure 1. Direction of movement of the system

Workers can be considered as a dissipative system, and each worker - as an open system that exchanges energy and entropy with the environment.

The entropy of the system is the sum of the composition of the various states probabilities of the system on the logarithms of these probabilities, taken with the inverse sign. It turns to zero when one of the states of the system is credible, while others are impossible. For a given number of states, it turns to a maximum when these states are equally probable, and it increases with increasing the number of states. Finally, and most importantly, it has the property of additivity, that is when united in one of the several independent systems, their entropies add up. The entropy of the system determines the direction of energy exchange, in the management theory - a measure of uncertainty of the state or behaviour of the system under these conditions [Олемской 2009, с. 67].

The entropy of the system is higher the greater the degree of system disorder. Thus, if the process goes in the direction of increasing disorder (this is the most probable process), then to increase the degree of order in the system it is necessary to spend extra energy. Thus, the bifurcation (Latin bifurcus) is a state of the system that determines its further development and is the result of disordered states in the middle of the dynamic system caused by an increase in fluctuations (Latin fluctuatio), to reduce which the system itself is incapable. In this case, the system of an individual-employee will be a fluctuation in the general layer that relates to the collective. Fluctuations are united, which is manifested by the unification of people in the form and some signs, for example, association by attitude to work, organization of security, professional training, etc. The union ends with the formation of dissipative structures on a common layer characteristic of the collective. 
The dissipation of ergative systems manifests in the ability to "forget" the details of some external actions, to select among a multitude of microprocesses, in their coherence, which establishes the general pace of development, and so on. Dissipative systems are highly non-equilibrium, and unstable states are possible in them. In such systems at a certain distance from the equilibrium state the fluctuations instead of attenuating (as in equilibrium systems), on the contrary, they amplify and begin to possess the whole system, forcing it to evolve to a new regime [Пугачева, Соловьенко 2003, с. 25-43]. The transition of the system after a critical point from an unstable state to a stable (to dissipative structure) can be considered as a qualitative leap in the development of the system, which resulted in increased organization, ordering the system (Fig. 2).

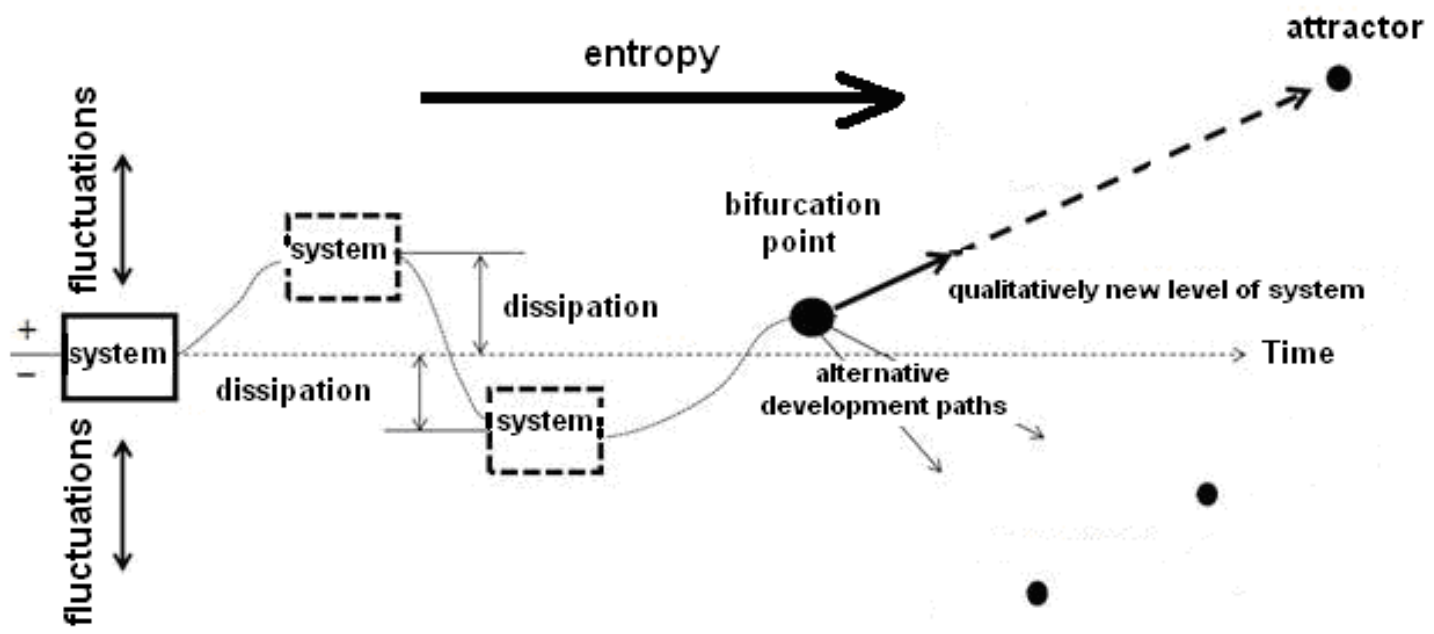

Figure 2. Scheme of the ergative system development in accordance with the synergetic theory

Consider the entropy behaviour more detail. The Belgian physicist I.R. Prigogine proposed the behaviour of open systems entropy to describe as the sum of the production of entropy in the system $d S_{i}$ and its exchange $d S_{o}$ with the environment. The indexes «i» and «o» denote the production and exchange with the external environment, respectively. Consequently, the general change of the entropy of an open system equals to sum [Аршинов, и др. 2000, с.98-120]:

$$
d S=d S_{i}+d S_{o}
$$

If we consider an open system, then the sign of entropy production is always positive, that is $d S_{i}>0$, and the sign of entropy exchange can be both positive $d S_{o}>0$ (inflow of entropy from the environment), and negative $d S_{o}<0$ (outflow of entropy from the system). 
Thus, may be cases when the total entropy of the system can be reduced or equal to zero, that is $d S \leq 0$. There are four possible situations:

1) entropy comes from the environment, that is, since $d S_{o}>0$, the sum of these quantities is also positive $d S>0$ and the system goes to the nearest state of equilibrium;

2) the outflow of entropy into the environment $d S_{o}<0$, but its absolute magnitude $\left|d S_{o}\right|<d S_{i}$. Thus $d S=d S_{i}+d S_{o}>0 ;$

3) the outflow of entropy into the environment $d S_{o}<0$ and its absolute value is equal to the entropy production $\left|d S_{o}\right|=d S_{i}$, then $d S=d S_{i}+d S_{o}=0$ we have a stationary process with unchanging general entropy. In this case, the system carries out some internal work with the generation of internal entropy;

4) the outflow of entropy from the system in the environment $d S_{o}<0$ its absolute magnitude more than the entropy production in the system $\left|d S_{o}\right|>d S_{i}$. So, in this case $d S=d S_{i}+d S_{o}<0$, their amount turned out to be negative.

Obviously, the open system is in an ideal "stationary state" under the condition:

$$
d S_{i}+d S_{o}=0 .
$$

In other words, "to maintain a stationary non-equilibrium state it is necessary to continuously send into the system a negative entropy flow equal to the size of the internal production of the entropy flow", i.e. $d S_{i}=-d S_{o}$. Thus, if the process goes in the direction of increasing disorderly system, $d S$ is positive. To increase the degree of order in the system $(d S>0)$ it is necessary to spend energy.

The personal factors of employees - their psyche, character traits, attitude to work, discipline, job satisfaction, and attitude to other members of the collective - are important in increasing labor productivity and preventing occupational injuries. Undoubtedly, labor productivity may be increased at the expense of the motivational factor of self-improvement for each employee. As Erwin Schrödinger, an Austrian theoretical physicist, one of the founders of quantum mechanics, wrote: «... a living organism continuously increases its entropy, or, in other words, forms a positive entropy and thus approaches a dangerous state of maximum entropy - death. He can avoid a such state, to remain alive only through the permanent removal of negative entropy from the surrounding environment, that is, 
the reduction of entropy due to the external influx of matter, the energy flow, and the receipt of information» [Малинецкий 2012, с. 125-138].

The Labor Productivity Management. The task of increasing productivity will be considered in the formation of increased resistance to crisis factors that appear on the individual layer of workers. In entering the motion factor to these states, causes the inevitable collision with the determination of bifurcation as a region of the metastable state of the moving system where it chooses path to equilibrium, which is a state that can be called the goal of achieving a system. Thus, the reaction of the system - a team of workers - to the external influence of the environment and on the excitation of one of the elements - the individual - will be one order, that the formation of a point of bifurcation is possible, which will cause the change of attractor and the emergence of an updated management system. Thus, open systems are maintained in a certain state due to the continuous inflow from the outside and (or) outflow of matter, energy, or information.

The environment that makes up a separate layer is understood as a system of material carriers for the expression or support of certain processes within the layer. For example, the inner motivation of an individual can be reflected in the inner layers of the system. Here, an analysis of the individual's social motivation in relation to the goal is needed, then the material layer necessary to reflect this motivation will be determined by the typical social structure in which there exists an individual focused on financial success. It is obvious that this layer is limited for the individual by his objective and subjective capabilities.

For an open system of the employee, in terms of managing his productivity, entropy can be considered a set of components such as:

- natural abilities (critical thinking, adaptability) $d S_{c}$;

- professional competence (knowledge, professional skills, digital transformation) $d S_{r}$;

- stress resistance to external stimulus (emotional resistance) $d S_{p}$.

The degree of influence of factors can be judged by their effectiveness on the inner layer, reflecting the basic concept of each person about his professional compliance. Therefore, the internal experiences of workers will always be associated with working conditions, moreover, they can be transferred to other members of the team (pass to the next layers). This fact is obvious, because in synergy it is known that the dissipative structures are born through the union of fluctuations. 
Thus, to manage employee productivity we can assume that each company is characterized by a set of indicators: $d S_{c}, d S_{r}, d S_{p}$. These indicators have different «importance» for different employees. It is therefore advisable to enter the appropriate coefficients $\mu_{\mathrm{c}}, \mu_{\mathrm{r}}, \mu_{\mathrm{p}}$ which increase or decrease the significance of the corresponding entropy.

Using the above-described notation the worker' entropy, that is internal entropy of the system, can be written by:

$$
H_{i}=\mu_{c} d S_{i c}+\mu_{r} d S_{i r}+\mu_{p} d S_{i p}
$$

where $d S_{i c}, d S_{i r}, d S_{i p}$ - the own parameters of an employee.

The conditions offered by the enterprise (external entropy) may be estimated by:

$$
H_{o}=\mu_{c} d S_{o c}+\mu_{r} d S_{o r}+\mu_{p} d S_{o p},
$$

where $d S_{o c}, d S_{o r}, d S_{o p}$ - minimum requirements for the employee from the enterprise.

To ensure employee equilibrium in a company it is necessary to get following condition:

$$
\begin{gathered}
H_{i} \geq H_{o} \text { or } \\
\mu_{c} d S_{i c}+\mu_{r} d S_{i r}+\mu_{p} d S_{i p} \geq \mu_{c} d S_{o c}+\mu_{r} d S_{o r}+\mu_{p} d S_{o p} .
\end{gathered}
$$

From this inequality it follows that:

$$
H_{i}=H_{o}+K,(1)
$$

where $\mathrm{K}$ - the value that determines the level of employee motivation at the enterprise. Expressing from equation (1), we obtain:

$$
K=\mu_{c}\left(d S_{i c}-d S_{o c}\right)+\mu_{r}\left(d S_{i r}-d S_{o r}\right)+\mu_{p}\left(d S_{i p}-d S_{o p}\right) .
$$

Values of $H_{i}$ and $H_{o}$ may change over time (Fig. 3). These changes may be due to lowering or increasing wages, increasing requirements for the company by the employee, etc. Point $\mathrm{B}$ is the equilibrium state. 


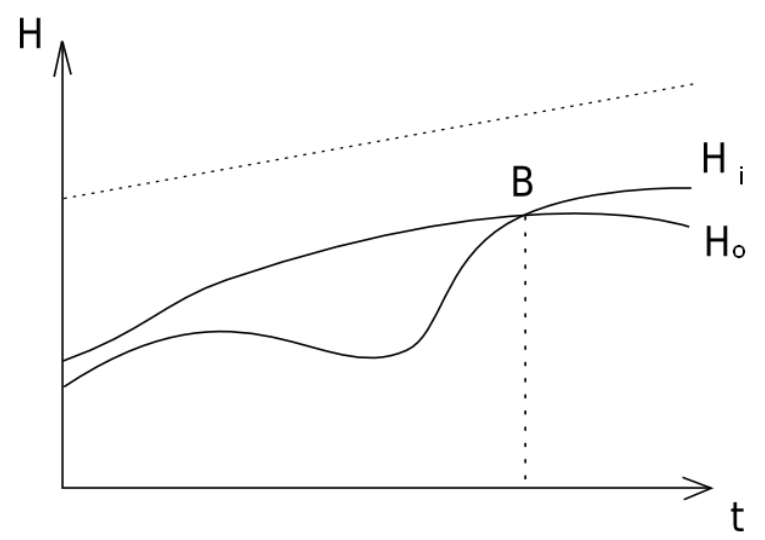

Figure 3. The scheme of dependence of the conditions required by the enterprise $\left(H_{O}\right)$ and requirements of the employee to the enterprise $\left(H_{i}\right)$ in the unstable system «employeecompany»

In the situation $H_{i}<H_{o}$ the appearance of a so-called bifurcation point in the worker's life is possible. At the level of the mathematical description, the bifurcation signifies the branching of the solutions of the nonlinear differential equation. The physical significance of the bifurcation is: this is the point of branching the paths of the evolution of an open nonlinear system. Thus, at this point, the employee can choose a different path of further development, different from the previous one. Examples of development options:

- the company reduces the requirements for the employee and he continues to work on it;

- the employee does not meet the requirements of the company and he leaves it;

- the company raises the motivation of the employee. The employee upgrades his qualification (enhance skills, is being trained) and continues to work at the enterprise [Беккер 2003, с. 37, 258-309].

To prevent the occurrence of bifurcation points in the "employee-company" system, the following conditions must be satisfy:

$$
\left\{\begin{array}{c}
H_{i}=H_{o} \\
\frac{d H_{i}}{d t}=\frac{d H_{o}}{d t} .
\end{array}\right.
$$

In fig. 4 a scheme of a steady state of the "employee-company" system is presented. The study and application of motivation systems at the enterprise will increase the efficiency of human resources and maintain the emotional health of workers. 


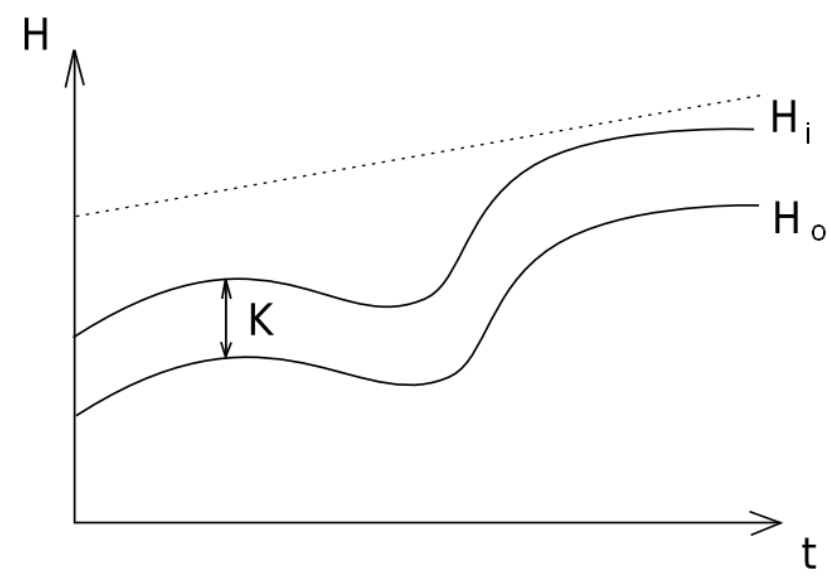

Figure 4. Scheme of the dependence of values $H_{i}$ and $H_{o}$ on time in a stable «employee-company» system.

Thus, with the proposed approach for each employee and for the company as a whole, it is possible to optimally increase the labour motivation of the workers, taking into account the specifics of the enterprise and general social conditions.

Conclusion. Application of synergetics to solving the problems of increasing productivity at the company will contribute to the growth of skills of employees and the improvement of productive relations on issues of work motivation of staff. Managing productivity is an important part of the management process at a company and an effective tool to increase its profitability. Application of synergetic methods to managing labour productivity, especially in crisis conditions, will make it possible to determine the criteria for organizing an effective working process, taking into account the self-organization of the safe behaviour of each employee. The task of improving the labor process is to create increased resistance to crisis factors occurring on the laboratory layer of individual workers. Thus, this approach will strengthen the motivation of labour at the enterprise, depending on the characteristics of the control parameters. The application of modern theoretical and practical approaches to managing of labour productivity in enterprises will create favourable conditions for activating factors that affect labour productivity and create real opportunities for its growth. 


\section{References}

1. Аршинов В.И., Буданов В.Г., Войцехович В.Э. Синергетическая парадигма. Многообразие поисков и подходов. - М.: Прогресс-Традиция, 2000. - 536 с.

2. Беккер Г. Человеческое поведение: экономический подход. Избранные труды по экономической теории. - М.: ГУ ВШЭ, 2003. - 672 с.

3. Єфімова О. Системний підхід - основа управління діяльністю підприємств// Персонал №2, 2007. - С. 67-72.

4. Малинецкий Г.Г. Математические основы синергетики. Хаос, структуры, вычислительный эксперимент. - М.: Либроком, 2012. - 314c.

5. Олемской А.И. Синергетика сложных систем: Феноменология и статистическая теория. - М.: Красанд, 2009. - 379 с.

6. Пугачева Е.Г., Соловьенко К.Н. Самоорганизация социально-экономических систем.- Иркутск: Изд-во БГУЭП, 2003. - 172 с.

7. Холод Б.І. Системний підхід - основа сучасного управління діяльністю промислових підприємств // Академічний огляд, 2010 № 1. - С. 48-51. 